\title{
Sobre a deíxe e os pronomes demostrativos
}

\author{
Xosé Manuel Sánchez Rei \\ Universidade da Coruña
}

\begin{abstract}
Resumo:
Este artigo está dedicado ao estudo dos demostrativos dun ponto de vista gramatical e tamén pragmático. Comeza coa súa morfoloxía moderna, as súas funcións sintácticas e o seu comportamento na deíxe. A este respeito, convén notarmos que os demostrativos galegos se organizan en tres parámetros deícticos, ao paso que, desde unha abordaxe sintáctica, poden desempeñar quer funcións de núcleo, quer funcións de adxacente.
\end{abstract}

Palabras chave:

Pronomes, demostrativos, deíxe.

\begin{abstract}
:
This work is devoted to the study of demonstratives from a grammatical and pragmatic point of view. It deals with the modern morphology, the syntactic functions of the pronoun and its behaviour in deixis. It is necessary to mention that the Galician demonstratives are organized in three different deictic fields and that they can work as nucleus of nominal phrases as well as adjacents.
\end{abstract}

Key words:

Pronouns, demonstratives, deixis.

\section{Definición e caracterización dos pronomes demostrativos}

\subsection{Definición}

\subsubsection{A tipoloxía de palabras a que pertencen}

Ao longo de toda a tradición gramatical, os demostrativos teñen sido identificados non sempre do mesmo modo, xa que foron incluídos, por exemplo, nos grupos de pronomes, nas tabelas de adxectivos, nas listaxes de pronomes adxectivos, nos paradigmas de determinantes, etc., sen que ficase demasiado clara, após un confronto de todas estas perspectivas, a que tipoloxía de palabras pertencen, pois compartillan trazos con todas estas. Na verdade, isto non ten a ver coas particularidades específicas desta clase de unidades gramaticais, mais coa noción e co signifi- 
cado que en cada momento se fixo corresponder á etiqueta "pronome", ou sexa, ora promocionando as súas ocorrencias como substantivo, ora ponderando a posibilidade de axir funcionalmente como un adxectivo. É de notar que esta heteroxénea visión histórica non se deu cos denominados pronomes persoais, que sempre foron identificados coa mesma nomenclatura e considerados como tais através dos estudos de lingüística, sen que houbese discrepancias sobre se podían ficar agrupados cos elementos substantivais ou se, polo contrario, era lexítimo consideralos desde outras perspectivas.

Un breve repaso ás principais gramáticas contemporáneas do ámbito galego-portugués corrobora a diferente consideración que mereceron esta clase de referenciais precisos. A primeira destas consideracións a que temos de facer referencia é a de Barboza (1830: 161-165), quen engloba os demostrativos no grupo dos "adjectivos determinativos", en que diferencia os "determinativos demonstrativos puros" dos "conjuntivos" (correspondendo respectivamente ao que hoxe denominamos pronomes demostrativos e pronomes relativos). Por súa vez, Saco Arce (1868: 58-60) considéraos pronomes sen máis, como farán posteriormente Lugrís Freire (1931: 34) ou Carré Alvarellos (1967: 66-67). En gramáticas máis próximas cronoloxicamente da nosa época ou inclusivemente actuais, son identificados cos mesmos parámetros, como se desprende de Carballo Calero (1979: 197-198), Cuesta / Luz (1989: 398-399), Cunha / Cintra (1992: 328-342), Costa / González / Morán / Rábade (1988: 105-109) ou Álvarez / Regueira / Monteagudo (1993: 207-213), estes últimos a definírenos como "unha clase semántica dentro dos determinantes". Finalmente, dos últimos contributos de que temos noticia, un deles denomínaos "pronomes e determinantes demonstrativos" (Vilela 1999: 217-221), ao paso que outros os consideran unicamente pronomes (Freixeiro 2000: 198-209; Freixeiro 2002: 114-117) e o máis recente, indicando as súas varias funcións, prefere denominalos xenericamente sob a nomenclatura de "demostrativos" (Álvarez / Xove 2002: 457).

A dupla responsabilidade sintáctica que son quen de desenvolveren aínda conlevou que pasasen a se empregar outras terminoloxías non tan restritas como as que os agrupaban funcionalmente cos adxectivos ou cos pronomes, mais un bocado independentes destas dúas consideracións; así as cousas, alternando coas anteriores, son igualmente usadas nomenclaturas como "termo primario" ou "termo secundario", a depender de se o pronome for núcleo da FN ou adxacente, respectivamente; tamén teñen certo uso terminoloxías como "adxacente nominal" e "determinante" ou "núcleo" fixándose se o demostrativo acompaña un nome, nas dúas primeiras, ou se se utiliza como nó da $\mathrm{FN}^{1}$, na terceira.

1 Deste modo, desde outros ámbitos ibéricos, Fernández Ramírez (1987: 97) é utente de nomenclaturas como "término primario o secundario", encanto Álvarez Martínez (1989: 105) os define como os "adjetivos determinativos más típicos". 
Na realidade, do noso ponto de vista, o que singulariza a clase pronominal non é a circunstancia de poder desempeñar ambas as funcións, a adxectival ou a substantival, como antes posuír unha serie de trazos que os singulariza dentro da lingua, e un destes, a posibilidade de se comportar sintacticamente como un núcleo da FN non é senón máis unha destas características. Para Fernández Ramírez (1987: 9798) é esta a circunstancia que os fai ingresar nas relacións de formas pronominais, pois os substantivos unicamente poden desempeñar funcións que el denomina "primarias". Os pronomes apresentan como característica fundamental seren elementos gramaticais, o que os opón aos nomes e verbos, que pertencen á componente lexical da lingua. O problema parte, pois, da identificación clásica de os pronomes se comportaren como os substitutos do nome, que ve como un paradigma morfolóxico determinado, alén de eventualmente desenvolver tal función, permite que os seus integrantes asuman outras responsabilidades ademais desta. Máis unha vez, os persoais tónicos suxeito serven aquí de contraponto, pois non admiten ser empregados extrasubstantivalmente pola súa propria natureza semántica, moi ao contrario do que acontece con outros sistemas, en que ben se toleran ambos os usos, ben se restrinxe unicamente a un, en ocasións só adxectival: lémbrese ao respeito o relativo cuxo, sempre a axir como adxectivo na lingua moderna, ou aínda o identificador definido cada, que opera igualmente con tais funcións.

Pola nosa parte, coidamos que non apresenta dificuldades de máis unha identificación de este, ese e aquel simplesmente como pronomes, que ás veces se comportan como núcleos da FN e en ocasións cumpren funcións de adxacentes por iren a acompañar unha forma que axe como substantivo, coa excepción das formas isto, iso e aquilo, que, no entanto, unicamente desenvolven funcións substantivais. No primeiro dos exemplos que citamos a seguir o demostrativo desempeña a primeira das responsabilidades sintácticas e a outra mostra corresponde á segunda das posibilidades de utilización:

\section{Ista dixo que collera un aire}

(Fole, LC 36)

Sabede que se casóu con aquel rapaz.

$$
\text { (Castelao, OC, I 402) }
$$

Canto ás particularidades flexivas, finalmente, os demostrativos receben os morfemas de xénero e número (este / esta, estes / estas, etc.), agás os pronomes invariábeis, que somente coñecen unha forma que concorda no masculino (Isto é certo, Todo iso fai parte dos planos de recuperación, Aquilo parecía bon, etc.). Por este motivo tais unidades son denominadas por Lagares Diez (2000: 208) "masculinos invariábeis", pois os mecanismos de concordancia obrigan o xénero masculino a harmonizar dentro da FN e da clásula cos elementos sen flexión. 


\subsubsection{As coordenadas referenciais de espazo como elementos básicos na súa definición}

Ora, deixándomos de lado a súa adscrición a unha ou a outra tipoloxía de palabras e as súas caracaterísticas morfosintácticas, ninguén dubida de que o seu carácter de mostración se torna unha das súas singularidades máis salientábeis. Aínda que o conceito de deíxe será tratado máis abaixo, podemos definir os demostrativos como aquelas unidades de pronomes referenciais precisos que asinalan unha determinada entidade no espazo ou no tempo, para cuxo labor se valen dun sistema trimembre $^{2}$ através do cal se indica o afastamento ou a proximidade a respeito do falante. Este triplo campo organizativo garda un certo paralelismo cun sistema de adverbios deícticos básico e da comparación entre ambos chégase á seguinte correlación, que vén sendo adoptada tradicionalmente polas diferentes gramáticas ${ }^{3}$, e que, como veremos máis adiante, apresenta algunha incoherencia a respeito da delimitación das coordenadas deícticas do emisor: $\mathrm{T}^{4}{ }^{4}$ este, aquí (proximidade do falante); T2 ese, aí (proximidade do ouvinte); T3 aquel, alí (afastamento tanto do falante como do ouvinte).

Neste sentido, adóitase notar unha estreita relación entre os pronomes persoais e os sistemas deícticos, de aí que costuma ser bastante habitual na literatura lingüística facer corresponder os demostrativos, tomando como base o binomio proximidade / afastamento, cos pronomes persoais a partir das tres persoas gramaticais, P1, P2 e P3, de forma que este ficaría na órbita deíctica de P1 (eu), ese estabelecería tal relación a respeito de $\mathrm{P} 2$ ( $t i)$ e aquel, pola súa parte, estaría no impreciso ámbito de P3 (el, ela). Así se pode ler, por exemplo, en Álvarez / Regueira / Monteagudo (1993: 213), en Álvarez Martínez (1989: 106) ou tamén en Vilela (1999: 217), este último a manifestar que os "pronomes demonstrativos têm proximidades com os pronomes pessoais", mais tamén "com os advérbios (sobretudo com os advérbios de lugar)".

Mais estas apreciacións, especialmente as que estabelecen pontos de contacto entre os adverbios aquí, aí e alí e os demostrativos, como tamén a simples univocidade entre as tres persoas gramaticais e as formas pronominais deícticas, non cobren

2 Na realidade, os sistemas trimembres de pronomes deícticos constitúen unha solución minoritaria, característica das linguas ibéricas, en confronto cos esquemas bimembres da maior parte dos idiomas europeus actuais, foren románicos ou non. Neste sentido, non deixa de ter interese a problemática que se deriva de aquí nas traducións entre o alemán, o inglés e o francés, dun lado, co galego e portugués, italiano literario (toscano), e español, doutro; véxase, a este respeito, Wandruszka (1976, II: 425-455).

3 Véxase Mattoso Câmara (1997: 123) ou tamén Álvarez / Regueira / Monteagudo (1993: 213).

4 De agora en diante, usaremos as abreviaturas T1 (primeiro termo da deíxe), T2 (segundo termo da deíxe) e T3 (terceiro termo da deíxe) para, respectivamente, as series de este / esta / isto, ese / esa / iso e aquel / aquela / aquilo. 
toda a caracterización de seu que apresentan tais pronomes e elementos adverbiais. Se, por exemplo, repararmos na correlación entre os pronomes demostrativos e os adverbios absolutos de lugar, é evidente que parece lóxica, en principio, a lista de correspondencias entre este, ese e aquel con aquí, aí e alí. O problema xorde cando se detecta unha notoria asimetría entre a serie pronominal e outras formas adverbiais, como aquén, acá, acó, as cais, ao lles procurarmos un correlativo pronome, terían de se asociar a este; por súa vez, alén, alá, aló e acolá semellan preferir o ámbito de aquel, mentres que para o caso de ese, embora algúns destes locativos poidan ser empregues nos seus dominios deícticos ${ }^{5}$, non existen horizontalmente caisquer formas respectivas. Hai que observar que pouco importa para elaborarmos tal correlación o facto de certos adverbios desta serie seren nomeadamente literarios ou proprios da lingua formal (aquén ou alén) ou aínda a circunstancia de a distribución entre acá / acó ou alá / aló ficar subordinada sobretodo a condicionantes de índole xeolingüística ou de carácter modal ${ }^{6}$, xa que en nengún destes dous marcos, o da lingua escrita e o da dialectoloxía, existen formas análogas de pronomes demostrativos para todas as formas adverbiais. O campo deíctico da clase mostrativa de T2 apresenta, pois, unha considerábel ausencia de correlatos adverbiais locativos se confrontado con T1 e T3, o que levou algún investigador a reorganizar tais adverbios absolutos en tres grupos a partir de este e aquel.

Por outro lado, é preciso reflectirmos se en expresións como "proximidade do falante", "proximidade do ouvinte" ou "afastamento do falante e do ouvinte" se indican relacións asumíbeis para mostraren con clareza os tres campos deícticos. Os demostrativos e os posesivos agrúpanse baixo a común denominación de referenciais precisos, mais a referencia é estabelecida de maneira concreta entre a P3

5 Así se recolle no esquema proposto en Álvarez / Regueira / Monteagudo (1993: 423), onde se indica que o campo deíctico de utilización de acolá abranxe tanto a esfera de ese como a de aquel.

6 Para a distribución xeográfica de acá / acó e alá / aló, véxase ILG (1995: 338-341), en que se aprecia que as formas en -á predominan con moito nas provincias de Pontevedra e Ourense, ao paso que os adverbios en -ó son característicos de Lugo e da Coruña. Por outra banda, Álvarez / Regueira / Monteagudo (1993: 424), ao distinguiren usos dos adverbios en -á dos acabados en -ó, apontan que "entre a serie en -ó e as outras [...] hai unha diferencia aspectual: movemento translocal -ó / repouso ou movemento intralocal -í, -á, acolá [...]. Aínda que é aconsellábel manter esta oposición, na lingua falada de grande parte de Galicia non existe máis ca unha soa destas series para ámbolos dous empregos". Véxase tamén Matos / Muidine (1997: 216), Costa / González / Morán / Rábade (1988: 240) e Pérez Sardiña (1996: 89-104).

7 Véxase Mattoso Câmara (1997: 124): “A nossa língua tem também um sistema de locativos, ou seja, de demonstrativos em função adverbial. Uma primeira série corresponde a este, esse e aquele [...]. Outra série, dicotômica, opõe cá, próximo do falante, a lá, distante do falante, com uma forma intermediária acolá, para em oposição a lá distinguir entre dois locais distantes ambos do falante. As duas séries interferem entre si, com uma variação livre entre cá e aqui (o português do Brasil marginaliza a forma cá) e o acréscimo lá à série aqui, aí ali para assinalar uma localização além de ali. Uma terceira série de locativos estabelece a posição não em função do falante, mas de um ponto qualquer que este toma como referência: a) antes desse ponto: aquém; b) depois desse ponto: além". 
coas tres persoas gramaticais polos posesivos (meu, teu, seu) ou ben coa primeira polos demostrativos. Esta circunstancia ten xerado que os pronomes que se aquí tratan fosen considerados en ocasións "egocéntricos" por estruturaren o mundo sensíbel a tomaren como base $\mathrm{P} 1^{8}$ e o ámbito da súa percepción. Na nosa óptica, xulgamos que se evidencia unha inadecuación teórica entre considerarmos tais pronomes como egocéntricos e afirmar que fan referencia ao falante, ouvinte ou a aquilo que fica fóra destes dous parámetros mostrativos; non se pode defender que o ponto de partida do asinalamento deíctico de este, ese e aquel se basea no emisor para, a seguir, indicar que T2 indica algo próximo do ouvinte (P2) e que T3 sitúa o que estiver perto daquilo que se falar (P3).

Mais a relación entre P3 e os demostrativos, seguíndomos Alarcos Llorach (1973: 61), é notoria: en todo o acto lingüístico existe un $e u$ e un $t i$, ao paso que as formas el / ela fican fóra desta programación locutiva; os pronomes este, ese e aquel non son senón especificacións de P3, entanto que contribúen para a súa determinación, sempre mostrando o ponto de afastamento / proximidade en relación ao emisor. Unha cláusula do tipo Estiven con el, na opinión do filólogo español, apresenta unha forma pronominal, el, que axe como arquilexema das tres series de demostrativos e no cal opera a neutralización de asinalamento que estas expresan.

Deste modo, no tocante a esa incoherencia antes comentanda e aos apontamentos de Alarcos Llorach, semella ser máis conveniente reformularmos a definición dos demostrativos cando efectivamente asumen funcións de indicación, as fundamentais, baseándonos en P3, que fica semanticamente afastada de P1 (e tamén de P2), e a combinármola coa súa ausencia real no acto comunicativo. Fica entón o esquema que segue, que non invalida a visión tradicional mais que nos parece dunha maior concreción ao contemplar unha outra distinción cal é 'ausente' / 'non ausente' ${ }^{\prime}$ tomando como referencia o ponto de vista do emisor, isto é, o carácter egocéntrico dos demostrativos:

$$
\begin{array}{c|l|l}
\text { Obxecto referenciado }- & \begin{array}{l}
\text { Ausente (T3): aquel } \\
\text { Non afastado } \\
\text { Nonsente (T2): ese } \\
\text { (T) este }
\end{array}
\end{array}
$$

8 Sustén Chaves de Melo: "Este, esse e aquele situam as coisas, as impressões, os conceitos, pondo-os ora no espaço, ora no tempo. O ponto de partida, o ponto de referência, é sempre o eu: daí que certos lingüistas falam em dêicticos egocêntricos" (Melo 1986: 379). Véxase tamén Freixeiro (2002: 114), quen igualmente os considera egocéntricos.

9 Desde postulados xerativistas, Raposo (1973: 367), por súa vez, identifica as tres series de demostrativos coa axuda dos trazos [+ Demostrativo, - Perto, - Lonxe] para este, [+ Demostrativo, + Perto, -Lonxe] no caso de ese e [+ Demostrativo, - Perto, + Lonxe] en aquel. 
É posíbel que con tal estruturación se poida pór en cuestión se o esquema organizativo dos demostrativos galegos é bimembre, apresentando un grau de especialización no índice 'afastado', xa que unicamente se considera a noción de arredamento a respeito do falante. Aínda así, parécenos discutíbel esa hipótese porque 'non afastado' tamén implica, tacitamente, 'non ausente', e porque unha das perspectivas tradicionais situaba este e ese dentro da dupla órbita do emisor-receptor e aquel á marxe de tal esfera, sen por iso formular dúbidas acerca da pertinencia funcional dos tres graus de asinalamento ${ }^{10}$.

Noutra orde de cousas, é preciso situarmos os demostrativos compostos modernos ${ }^{11}$ estoutro, esoutro e aqueloutro no marco do asinalamento inicial expresado mediante

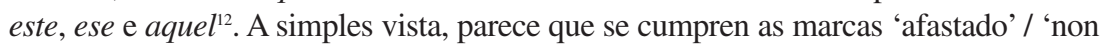
afastado' e 'ausente' / 'non ausente' asinaladas, de modo que, nun primeiro achegamento, sería igualmente válido o cadro proposto con anterioridade. Mais o valor de identificación que conleva un dos elementos de que se compoñen, o pronome outro, repercute en que a súa utilización non se poida reducir ao esquema inicial cando se empregan correlativamente ora cos demostrativos simples ora sen estes. Apesar de seren posíbeis usos correlativos entre este / estoutro, este / aqueloutro, ese / esoutro, etc., o facto de utilizarmos as formas compostas indica unha contraposición en que o carácter identificador destas, como se torna obvio, conleva unha distinción entre dous obxectos que están situados nos mesmos dominios mostrativos (T1, T2 e T3), mais que non deben de se confundir. Resulta así o seguinte esquema, en que se os valores iniciais se non alteran e ao cal se acrecenta a idea de contraste que proporciona outro:

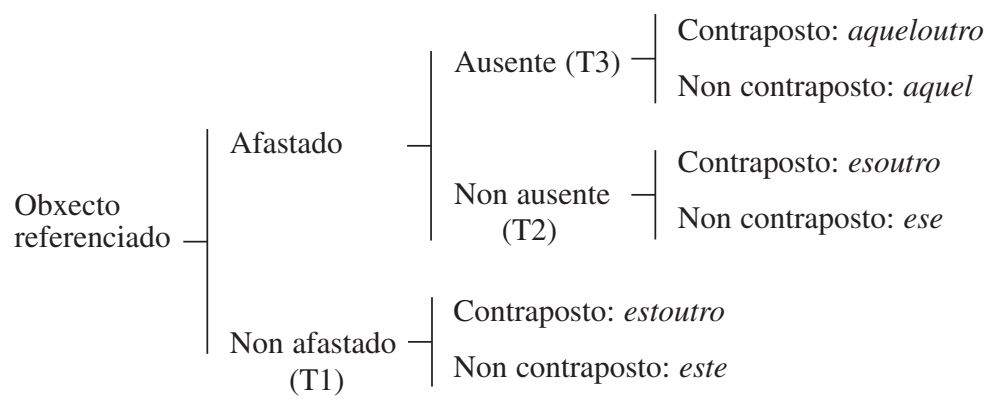

10 Véxase Álvarez Martínez (1989: 106): "Puede también decirse, como prefieren otros autores, que este y ese se refieren al campo cercano al hablante y su interlocutor (esto es, la proximidad), mientras que aquel hace alusión a lo que está lejos de las dos primeras personas (la lejanía)”.

11 Denominado tamén "demostrativo de alteridade" en Álvarez / Xove (2002: 467).

12 É tamén posíbel, no entanto, que ambos os pronomes, o demostrativo e o identificador, non se aglutinen e, en consecuencia, que fiquen as dúas unidades formalmente separadas: este outro, ese outro, aquel outro. Esta é a solución que triunfou no portugués, pois desde a súa variedade padrón os pronomes compostos ora son adoito considerados rexionalismos, ora popularismos. As formas invariábeis, contodo, nunca forman compostos con nengunha unidade dos identificadores: isto outro, iso outro, aquilo outro. 
Do ponto de vista da morfoloxía, estoutro, esoutro e aqueloutro englóbanse dentro das palabras compostas ao seren formadas por dous elementos. Ora, dentro do mecanismo xeral de composición de palabras, que distingue entre compostos lexemáticos, gramaticais e frásicos, os pronomes comentados nas liñas precedentes fican delimitados por pertenceren á segunda tipoloxía, que apresenta como característica o facto de, polo menos, un dos protagonistas do procedimento xerador de novas unidades ser palabra gramatical, recoñecíbel por se agrupar en paradigmas fechados. É o mesmo proceso, pois, que se observa en dezanove (dez + nove), dezasete (dez + sete $)$, etc.

Canto ao funcionamento dos demostrativos compostos, finalmente podemos afirmar que se empregan "cando se quer manifestar a escolla entre dous termos que se contrapoñen" (Freixeiro Mato 2000: 200). A presenza ou a ausencia dos dous pronomes, o simples e o composto, leva a falarmos de usos correlativos e non correlativos, a saber:

a) usos correlativos coa mesma esfera deíctica:

Séntate n-esta pedriña

qu'eu me sentarei n-estoutra

(CPG, I 209)

b) usos correlativos con distinta esfera deíctica, en que se ve ponderado o carácter de contraposición:

Séntate nesa pedriña

eu sentareime nesoutra

(POGA, I 260)

e c) usos non correlativos, en que tanto o emisor como o receptor compartillan a mesma referencialidade deíctica grazas ás súas capacidades intelectuais e non se torna preciso explicitar a contraposición:

Fogueiras de lume por aquí, fogueiras de lume por alí,fogueiras de lume por acolá, demos con, con corno na testa moi grandes; nestoutra banda vén outro demo

(adaptado de Fernádez Rei / Hermida Gulías 1996: 53)

\section{A deíxe}

\subsection{Definición e tipos}

Sería ben difícil imaxinarmos unha lingua sen elementos que, dependendo do contexto, puidesen mostrar ou asinalar determinados obxectos ou cousas para que o interlocutor teña a posibilidade de os indentificar. De facto, dentro dos mecanismos de que se serve a linguaxe humana para desempeñar tal sorte de funcións, existen 
dominios que exceden a propria linguaxe verbal e van aínda máis aló, como os movimentos da cabeza para apontaren unha entidade real, as indicacións realizadas coa man, co dedo ou co brazo, etc. A circunstancia, portanto, de asinalar algo para poder ser aprehendido polos interlocutores séntese como unha das máis elementares necesidades de caisquer idiomas, e até se ten afirmado, inclusivemente, que a orixe da linguaxe cómpre pórmola en estreita relación con tais necesidades, consoante as teorías de Brugmann (véxase Bühler 1979: 105) ${ }^{13}$. Para Wandruszka (1976, II: 428), os pronomes e os adverbios demostrativos, isto é, os elementos gramaticais de que dispoñen os idiomas para mostraren, non son senón fórmulas fónicas da necesidade humana de indicaren e hai que os relacionar cos recursos antecitados, decerto máis primarios, como os xestos levados a cabo coa man, co brazo, etc.; consoante a opinión deste estudioso, tais elementos gramaticais, "palabras deícticas especiales", serven para clarexaren o asinalamento desenvolvido con algunha parte do corpo. A cuestión enlaza cunha das diferenzas entre a comunicación humana e a dos animais, pois, para alén doutros aspectos que permiten distinguirmos ambas, a capacidade de asinalamento pertence ao ser humano; os restantes seres vivos do mundo animal poden berrar ou poden emitir sons con máis ou menos unha serie de funcións, mais, como di Bühler (1979: 105), aínda non sinalan.

De todo isto se conclui que a capacidade de asinalar ou indicar é de suma relevancia na linguaxe humana, tanto pola presunta orixe desta na necesidade de mostrar, como tamén pola precisión que se necesita para utilizar con corrección a lingua, de especial transcendencia nos estadios en que se está a aprender. Esta capacidade recebeu orixinalmente o nome de deíxe, 'asinalamento', e a ela é que imos dedicar o que resta destas páxinas. Para expormos as súas tipoloxías de deíxe de que podemos dar conta no noso idioma, seguimos moi de perto o contributo de Fonseca (1996: 440444) desde unha perspectiva tanto estritamente lingüística como pragmática ${ }^{14}$.

\subsubsection{Deíxe polo tipo de contexto compartillado}

Para esta primeira modalidade continúa a ser fundamentalmente válida aínda hoxe a xa clásica distinción de Karl Bühler ('ad oculos', reflexiva e amnésica), que

13 Bühler (1979: 103), compilando diversas nocións e variantes do valor da indicación na linguaxe humana, denomina a crenza de que esta procede do asinalamento inicial como "mito del origen déictico del lenguaje representativo". Tal mito ficaría enmarcado dentro das teorías sobre o aparecimento da linguaxe coñecidas como biolóxicas e antropolóxicas, vinculadas ao positivismo naturalista, que son opostas ás hipóteses teolóxicas e metafísicas, en que se prioriza a acción dunha entidade superior ao home como a base da linguaxe. Véxase, a respeito das liñas argumentativas básicas de ambas as explicacións clásicas, Roca-Pons (1982: 8-11); é tamén de utilidade o traballo de Alonso (2000).

14 Véxase tamén Porto Dapena (1986: 106), quen, baseándose unicamente nos pronomes demostrativos, distingue unha deíxe real face a unha discursiva; dentro daquela diferencia a deíxe espacial (obxectiva ou subxectiva) e a temporal, ao paso que nesta isola unha espacial e temporal. 
tamén se pode identificar, en harmonía con Fonseca, como indicial, textual ou transposta, terminoloxía que será a que nós imos adoptar aquí.

1. Por deíxe indicial enténdense os mecanismos con que se recollen informacións relacionadas cun ponto locativo determinado, que se expresan adoito mediante certos adverbios ou através de determinados pronomes ${ }^{15}$. No tocante ás diferentes denominacións con que a deíxe indicial figura tratada na literatura lingüística, algúns autores falan de exófora, isto é, un tipo de 'deíxe exterior' ou 'deíxe situacional', tal como figura en Halliday / Hasan (1976: 18-19) ou en Kleiber (1994: $43)^{16}$. A este respeito, parécennos moi acaídas as observacións de Fonseca (1996: 440-441), en que, sen rexeitar con rotundidade tal nomenclatura, matiza que non é totalmente correcta, xa que o contexto situacional, a se constituír desde un acto verbal, non é exterior á linguaxe. Con efeito, é esta a que estrutura as coordenadas locativas dos intervenientes do discurso, de aí que se deba á capacidade humana da comunicación verbal a organización dese mundo biosocial.

A depender da percepción e de dita estruturación do espazo, cada lingua vai diferenciar un número concreto de esferas deícticas, cuxos procedimentos máis salientábeis son dispor a locación con dous ou tres termos de deíxe; de aquí resultan os sistemas bimembres ou dicotómicos, en que se priorizan unicamente dúas esferas, ou os trimembres ou tricotómicos, en que son pertinentes tres campos de asinalamento. Para o caso do galego (e do portugués), é funcional a tripla distinción, embora a distinción non sempre parece ser efectiva nalgunhas áreas do noso sistema lingüístico, cal o caso de certos falares brasileiros a termos en conta as impresións de Mattoso Câmara (1997: 124) e de Teyssier (1989: 146) ${ }^{17}$.

15 Ramallo (2000: 470), no entanto, indica que non sempre "hai coincidencia entre o lugar da codificación e o lugar da recepción. De feito, hai situacións contradictorias dende o punto de vista comunicativo. Pénsese en casos nos que o interlocutor non se atopa no mesmo espacio físico có emisor, como acontece na comunicación a distancia, no intercambio epistolar ou nas chamadas telefónicas". Tal casuística de fenómenos, ao noso ver, non son senón máis unha mostra do carácter da referencialidade antes aludido que se manifesta nos deícticos, o cal permite que a comunicación, apesar destas aparentes incoherencias, non se vexa alterada.

${ }^{16}$ Halliday / Hasan (1976: 18), por exemplo, matizan que a referencia exofórica non é cohesiva, ao paso que Kleiber (1994: 43), por súa vez, opón deíxe exofórica á deíxe endofórica (de que falaremos máis adiante), por esta ser textual.

${ }^{17}$ Así e todo, non parece concordar con estes investigadores Bechara (1974: 321-322), quen ten serias dúbidas de que a simplificación de tres termos a unicamente dous sexa un proceso concluído ou cando menos maioritario: "Do exame de textos escritos -ainda aqueles vazados num registro coloquial para atingir, con eficiência, um público numeroso e heterogêneo-, pode-se chegar facilmente à conclusão de que a época dessa simplificação no sistema gramatical do português ainda está muito longe, pois que tais textos reflectem uma consciência viva das oposições estabelecidas pela gramática entre os demonstrativos este / esse / aquele". É importante non perdermos de vista o facto de que o texto que o levou a formular tal impresión responde a un estilo que é, nas súas proprias palabras, un "excelente representante do uso da linguagem coloquial escrita do português do Brasil", como é o caso da obra de Fernando Sabino intitulada A mulher do vizinho. 
En relación a isto, cómpre salientarmos, aliás, que a programación mostrativa mediante só dúas ou tres series de pronomes non se torna na única posibilidade. Aínda que, na opinión de Comrie (1989: 51), a utilización de pronomes (deícticos) para se referir ao falante e ao ouvinte constitui un universal lingüístico, o certo é que os sistemas trimembres ou bimembres, sendo moi comúns, non obstan para que o asinalamento se organice através de máis ámbitos mostrativos de acordo coa estrutura de cada idioma. Deste modo, Ramallo (2000: 470) salienta o tlingit, lingua atabascana falada en Alasca, que apresenta catro ámbitos de asinalamento: yáa ('este de aquí mesmo'), héi ('este de aquí perto'), yóo ('aquel de alí') e wée ('aquel moi afastado e adoito invisíbel').

2. No que se refere á deíxe textual, o campo perceptivo común corresponde neste caso ao contexto verbal, recuperábel polas capacidades memorísticas dos eventuais interlocutores. Son moi correntes, neste sentido, paráfrases tipo 'o que vén de ser dito' e 'o que vai ser dito', que aluden ás relacións intratextuais de anáfora e de catáfora, respectivamente. En tais casos é que cómpre falarmos de referenciación textual e distinguirmos entre a anáfora, que recupera algo xa mencionando con anterioridade, e a catáfora, que cobra sentido a considerar o que aínda non foi introducido no discurso ${ }^{18}$. No que di respeito á súa diferenciación coa deíxe indicial, aquí cobra sentido falarmos de endófora, xa que os segmentos discursivos preceden ou posceden a explicitación da marca deíctica. Os seguintes exemplos ilustran ambas as posibilidades de uso lingüístico, o primeiro unha referencia anafórica e o restante unha ligazón textual catafórica:

Unha muller que se casou con un home tolo díxolle que, mentres ela iba á feira, que lle tiña que coidar os pitos, amasar o pan e coidar o neno.

Así que marchóu ela, foise o home moi disposto a facer o que lle mandaran

$$
\text { (CLU 69) }
$$

A devoción que che tiven pagáchesma ben con esto: jandar con velas e misas para sair perdendo o preito

(Lamas Carvajal, $S G$ 113)

18 Para Cornish (1990: 82-83), quen parece partir do sentido básico do termo deíxe, existe unha diferenza entre esta e a anáfora propriamente dita: "Au niveau du discours, la fonction de l'anaphore se définit par rapport à la déixis: toutes deux représent des moyens de coordonner, de 'mettre sur la même longueur d'onde' l'attention des participants à l'acte de communtication [...]. Alors que la fonction prototypique de la déixis est de déplacer le centre d'attention (le 'focus') existant vers un nouvel objet du discours, celle de l'anaphore est de maintenir et de confirmer le centre d'attention déjà établi'. 
3. A deíxe transposta, por súa vez, coñecida tamén por 'deíxe proxectada' seguindo a nomenclatura de Fonseca (1996: 441), apresenta como características, por un lado, o facto de non existir nengún tipo de evidencia real que posibilite o acto de mostrar, quer fose mediante a percepción sensorial, quer fose através das relacións textuais de anáfora e catáfora. A súa fenomenoloxía, portanto, reside nunha "evidência mental", que naturalmente teñen de compartillar os intervenientes no discurso. Con este tipo de deíxe, o falante refere algo que non está presente no momento da enunciación, mais que é perfeitamente asimilábel polo interlocutor grazas ás súas capacidades intelectuais. O emisor transpón a persoa que o escoitar para esa situación real ou irreal "supondo (ou sabendo) que o interlocutor conhece o lugar em questão e que pode também 'transpôr-se' mentalmente para lá; trata-se de uma mostração 'in absentia', logo, de uma mostração fictiva'" (Fonseca 1996: 441). O seguinte fragmento, tirado dun texto literario, representa un tipo de deíxe transposta:

Tívose que baixar o Manoliño, de xeito que lle dise a lus dos faros no carrelo. Por medo de nos esfragare. Arrepiaba mirar para aquiles derrubadoiros da nosa mao esquerda

(Fole, HNC 27)

\subsubsection{A deíxe segundo a componente do contexto}

Nestoutra tipoloxía non prima o tipo de contexto que se compartillar, mais a utilización dos deícticos como motivadores semánticos das diferentes componentes do contexto comunicativo. Segundo estas, pódense distinguir tres tipoloxías de deíxe, como son a persoal, a social e a temporal e, eventualmente, unha cuarta, chamada circunstancial ${ }^{19}$.

1. A primeira refere a función dos signos deícticos que amosan o rango dos participantes nun acto verbal, de aí que os pronomes persoais EU e TI indiquen necesariamente os intervenientes na situación comunicativa e EL/ELA, polo contrario, o que non participa. Para caracterizaren o papel dos interlocutores no esquema comunicativo, consoante Ramallo (2000: 473), existe diverxencia de pareceres canto ao estatus da persoa gramatical. Fonseca (1996: 442), quen se basea en Benveniste

${ }^{19}$ Dentro destes parámetros da componente do contexto, Fonseca (1996: 443) distingue tamén unha deíxe espacial, que "gramaticaliza a noção deíctica de localização no espaço relativamente ao AQUI enunciativo". Na nosa opinión, porén, coidamos que esta tipoloxía de deíxe é doadamente reducíbel á anteriormente apontada como 'indicial' a teor do exemplo con que a estudiosa ilustra tal modalidade: Esta mesa é máis larga do que aquela: fica melhor aqui do que ali [a negra é nosa]. Nótese que nesta mostra se manifesta tamén o que define a indicial, pois "a possibilidade de mostração assenta, aqui, numa evidência deíctica, quer dizer, na presença, no contexto situacional, daquilo para que se aponta" (Fonseca 1996: 440). 
(1966), parte da categorías persoa (EU-TI) e non-persoa (EL/ELA); é pertinente a este respeito distinguirmos que EU e TI non teñen como referente a individualidade de algúen, mais "apenas o seu estatuto de participante num acto verbal", oposto ao EL/ELA, isento de tal rango de participación. Joly (1987: 67), por súa vez, discrepa especialmente no tocante á terceira persoa, xa que, logo de estabelecer unha distinción entre as persoas interlocutivas (EU e TI) e persoas delocutivas (EL/ELA), conférelle á P3 o rango de persoa ausente, facto que contrasta con Benveniste e con Fonseca, en que P3 non é persoa ausente mais ausencia de persoa. Diferente postulado destes dous parece ser o de Beaugrande / Ulrich Dressler (1997: 231-232), en que tanto a primeira e a segunda como a terceira persoa son consideradas participantes na interacción comunicativa.

Na maior parte das linguas, os pronomes persoais son os elementos lingüísticos que polarizan esta tipoloxía de deíxe. É importante lembrármonos de que a terceira persoa posui de seu mecanismos morfolóxicos que contribúen para a súa singularización a respeito das outras dúas (P1 e P2), como son as flexións de xénero e número (el / ela, eles / elas), e non é menos importante traermos á memoria, tamén, que tal entidade gramático-semántica tiña un estatus particular no latín ao non existir un pronome específico paralelo a P1 e P2. Doutro lado, a respeito das anteditas particularidades flexivas, mesmo hai linguas en que existe unha diferenciación de formas dentro desta a depender da condición xenérica, como o caso do inglés he / she.

Por último, cómpre subliñarmos que a deíxe persoal é a tipoloxía fundamental de modalidade deíctica. Con efeito, malia o espazo ser unha noción elementar para a concepción da deíxe, a orixe desta parte da localización dos falantes, que só nun segundo momento comezan a indixitar aquilo que os rodear. $\mathrm{O}$ espazo en que se leva a cabo o proceso mostrativo non existe antes do acto da enunciación, como aponta Fonseca (1996: 443) ${ }^{20}$.

2. A denominada como deíxe social ${ }^{21}$ é un conceito debido a autores como Lyons e Fillmore e consagrado durante a década de 60 e de 70; proba desa consagración é o facto de se a ela referiren investigadores actuais cal Fonseca (1996: 443), Vilela (1999: 409) e Ramallo (2000: 475). De acordo con este último, as linguas non organizan unicamente as "pautas espacio-temporais ou a posición física dos interlocu-

20 Di tamén Fonseca (1996: 443): "Embora o espaço, por ser a dimensão mais concreta, esteja na base do conceito de localização inerente à deixis, não é aceitável o ponto de vista, muito corrente, segundo o qual a deixis espacial é a forma primaria de deixis, dela derivando todas as outras".

${ }^{21}$ A este respeito, Vilela (1999: 4099 prefere falar de "deixis de base", determinada por un "conjunto de elementos que marcam o espaço e o tempo criados pelo discurso e a sua relação entre falante e ouvinte", e opola á "deixis social [...], a que diz respeito à relação social entre os participantes no discurso, como é a escolha, nas formas de tratamento, entre Tu-Você-Vocemeçê-Senhor e o uso dos tratamentos honoríficos como professor, sôr dôtôr, doutor, $v^{a}$ excia, $v^{a}$ senhoria, eminência". 
tores nunha situación" determinada, mais tamén son quen de gramaticalizaren certos aspectos que teñen a ver cos roles sociais asignados aos participantes nos actos de fala. En tais casos, achámonos coa antecitada deíxe social, a cal marca efectivamente diferentes graus de hierarquía, distancias e proximidades entre as persoas que fan parte do discurso, mais unha tipoloxía de distancias de natureza sociolóxica e non mostrativa.

O sistema de tratamento, organizado en cada lingua de acordo coa súa propria historia, é o exemplo máis representativo desta tipoloxía deíctica ${ }^{22}$. En galego, como é sabido, a distinción parte de $t i$ e vocé ou vostée ${ }^{23}$, o primeiro empregado para os usos máis ou menos familiares e os segundos para aqueles contextos en que a intimidade non é tan acusada. Por meio das dúas formas, pois, transparecen no uso lingüístico nocións como familiaridade, formalidade, relacións de poder, respeito, afectividade, estatus social, educación, etc. Na seguinte mostra, obsérvase como a rapariga Lela, vinculeira nova dun pazo, atúa os criados e como estes se dirixen a ela, contrastivamente, co tratamento de respeito en terceira persoa:

Lela - Eu vos axudarei.

Maruxa - Vaise poñer perdida, señorita

(Quintanilla, DO 73)

As relacións sociais e o tipo de educación poden modificar, como é obvio, esta chamada deíxe social e os elementos con que se manifesta. O tratamento de vós utilizado para un só interlocutor xa non é tan frecuente na actualidade como o era hai certo tempo, por exemplo no século XIX, de que a lingua de Rosalía é unha boa mostra. Do mesmo modo, a diferenciación entre $t i$ e vocé está suxeita aos condicionantes que a propria sociedade marca: como indica Ramallo (2000: 477), durante moito tempo no noso país "un fillo dirixíase a seus pais utilizando o pronome de respecto, en especial no mundo rural [...]. Na actualidade este uso está practicamente desaparecido", de xeito que no mundo citadino $t i$ está a desprazar gradualmente o correspondente pronome de respeito, facto que "pode verse como unha transformación sintomática das relacións sociais cara á igualdade".

3. Por outra banda, o correlato na marcación e identificación do tempo en relación ao espazo vén determinado através da deíxe temporal, segundo a cal podemos delimitar o tempo en que se produce o acto comunicativo, que non ten a obriga de facer

\footnotetext{
${ }^{22}$ Outros exemplos que asinala Ramallo (2000: 476) como exponentes da deíxe social son os termos de parentesco, tan recorrentes nalgúns dos manuais clásicos de sociolingüística para ilustraren as relacións entre a sociedade e a lingua e as diferenzas entre as distintas colectividades humanas no tocante á utilización do idioma.

${ }^{23}$ Ou vostede, segundo os criterios normativos oficiais.
} 
coincidir necesariamente o tempo da codificación co da recepción. Apresenta, no entanto, unha singular diferenza a respeito da deíxe indicial, xa que o tempo é apreso "nunha única dimensión, polo que dicimos que se trata dunha categoría lineal" (Ramallo 2000: 471). Un acontecimento ten de vir ordenado por vía de regra antes, simultaneamente ou despois dun outro, o que vén reflectido en certas linguas por meio do esquema temporal dos verbos pasado / presente / futuro ou dos adverbios tipo onte / hoxe / mañá. Para un achegamento á deíxe que se manifesta na conxugación do verbo é xa clásico neste sentido o par opositivo actual / inactual que asinala Pottier (1972: 98), segundo o cal, nos tempos do indicativo, resulta o seguinte esquema:

$\begin{array}{llll}\text { Actual: } & \begin{array}{l}\text { Pretérito } \\ \text { (cantei })\end{array} & \begin{array}{l}\text { Presente } \\ (\text { canto })\end{array} & \begin{array}{l}\text { Futuro } \\ (\text { cantarei })\end{array} \\ \text { Inactual: } & \begin{array}{l}\text { Antepretérito } \\ (\text { cantara })\end{array} & \begin{array}{l}\text { Copretérito } \\ (\text { cantaba })\end{array} & \begin{array}{l}\text { Pospretérito } \\ (\text { cantaría })^{24}\end{array}\end{array}$

Os adverbios de tempo son os exemplos estrela de elementos deícticos temporais, ao lado de procesos lexicais en que se asinala a distancia ou a proximidade a respeito do momento temporal da enunciación. Loxicamente, cada lingua apresenta a súa propria organización dos índices deícticos temporais, que non teñen de coincidir, como é obvio, entre si; Ramallo (2000: 472) cita como o persa posui palabras independentes para dous días antes e dous días despois ao conceito de hoxe, ao paso que o ruso e o xaponés diferencian tres para cada noción temporal. No galego común vigoran as formas onte e antonte, encanto adverbios ou locucións adverbiais como trasantonte, o outro antonte, antes de antonte, etc., parece seren máis minoritarias.

4. Finalmente, a deíxe circunstancial, denominada tamén por deíxe nocional ${ }^{25}$ ou deíxe modal, posui como máximo exponente o adverbio xenérico así, que é adoito empregado para activar semanticamente outros elementos do contexto (Lopes 1985: 91). O deíctico polivalente así, aliás, garda unha estreita relación con construcións tamén modais, cal deste xeito, deste modo, desta maneira, etc., moi rendíbeis, por outro lado, como recursos cohesivos Nos dous casos seguintes, tirados da

${ }^{24}$ Preferimos as denominacións de Antepretérito, Copretérito e Pospretérito en vez das tradicionais, respectivamente, de Máis que perfeito (ou Pluscuamperfeito), Pretérito Impefeito e Futuro do Pretérito (ou tamén Condicional ou Futuro Hipotético). A nova nomenclatura no discurso lingüístico galego foi asentada por Costa / González / Morán / Rábade (1988: 15) e goza xa dunha notábel implantación, como ben o demostra o ser adoptada polas gramáticas máis recentes publicadas (Freixeiro 2000: 311; Freixeiro 2002: 138; Álvarez / Xove 2002: 244-245).

25 Véxase Pottier (1977: 234-238), quen na súa tipoloxización da deíxe unicamente considera a espacial, a temporal e a nocional 
poesía pondaliana, así cumpre funcións moi próximas ás anafóricas, no primeiro exemplo, e moi perto das catafóricas, na restante mostra:

“[...];Ouh Castro, ben se conoce

que naceches desleirado,

entre soldados e muros,

e calabozos e escravos!"

Así decía Hermesinda [...]

(Pondal, QP 62)

E así cantou Margaride,

bardo da voz singular:

"A fror garrida da gandra,

que no doce mato está,

no seu tallo randeándose

ó sopro do vento soán,

ó abrigo das irtas uces,

nais á súa tenra edá,

que da tollente gïada

acougo doce lle dan [...]"

(Pondal, $Q P$ 96)

\subsection{Particularidades dos demostrativos en relación á deíxe}

Máis arriba facíamos notar a importancia que teñen os pronomes demostrativos para a organización e estruturación da deíxe, até o ponto de algún estudioso, partindo do conceito tradicional do termo, chegar a apontar que tais elementos gramaticais, xunto aos adverbios deícticos, non son senón fórmulas fónicas da necesidade humana de mostraren (Wandruszka 1976, II: 428). Con efeito, tense ponderado que tais unidades son as deícticas por excelencia, afirmación que nós non pretendemos negar mais matizar, pois, á vista das tipoloxías de deíxe comentadas na sección precedente, non apresentan unha distribución equidistante canto ao uso en todas as modalidades daquela; son, por exemplo, pronomes absolutamente básicos na deíxe indicial (por asinalaren algo ou alguén indicando a súa proximidade ou afastamento a respeito do binomio falante-ouvinte), secundarios na deíxe textual (por existiren outras formas capaces de a desenvolveren con similares ou idénticos resultados, como veremos máis abaixo), case anedóticos na deíxe social (que vén definida en grande parte polos sistemas de tratamento) e completamente laterais na temporal (en que unicamente gardan unha certa correlación no tempo ao esta se estabelecer polas nocións de pasado, presente e futuro). 
Neste apartado de imos achegarnos ás particularidades dos demostrativos en relación ás tipoloxías pragmáticas de deíxe que asinalamos anteriormente e comprobarmos cal é o seu comportamento en relación a aquelas. Para tal fin, parece pertinente unha visión que considere como ponto de partida os dous ámbitos básicos deícticos: o contexto que se compartilla co intelocutor e a componente do contexto.

\subsubsection{Deíxe polo tipo de contexto compartillado}

1. Xenericamente, dentro da deíxe indicial, T1, T2 e T3 encarréganse de asinalaren os graus con que se manifesta a proximidade e afastamento a respeito das persoas intervenientes no acto comunicativo: T1 refere algo non afastado, ao paso que T2 se emprega para algo afastado mais non ausente do campo mostrativo do interlocutor e T3, respectivamente, para algo afastado e ausente:

En jamás ó infeliz decir poidera

- ;Esto que teño é meu! -, qu'á sorte dura

N'inda por conceder lle concedera

(Rosalía, CG 137)

O Roxo deitoume á orella:

- As figueiras son esas

(Blanco-Amor, $O B$ 21)

¿Que estrelas aquelas son

que así relucen no ceo?

(POGA, I 462)

Ora, a clasificación canto ao uso no asinalamento indicial que se fai para T1, T2 e T3 só é pertinente na linguaxe falada, xa que na literatura e, en xeral, na lingua escrita, non existe unha realidade biosocial que haxa necesariamente que organizar deste modo. Isto é o que explica que Kock / Gómez Molina (1992: 12-13) ponderen o carácter anafórico dos demostrativos no nível gráfico, só ficando a mostración indicial para casos moi concretos ${ }^{26}$, ao paso que cuestionan que na oralidade os demostrativos posúan o mesmo correlato que se manifesta nos rexistos escritos. Contodo, o facto de que predomine a deíxe textual na escrita non é sinónimo de que a indicial non ocupe unha serie de parcelas en que é absolutamente necesaria, como é o caso do xénero teatral, e en particular das didascalias con función mostrativa, pois mediante as indicacións feitas polo dramaturgo estrutúrase o espazo dramático en que decorre a acción da obra.

${ }^{26}$ Afirman estes autores que "en la lengua escrita los pronombres sólo pueden ser anafóricos, puesto que sin antecedente carecen totalmente de sustancia informativa. Pueden ser deícticos en condiciones precisas y convencionales" (Kock / Gómez Molina 1992: 12-13). 
2. No ámbito da deíxe textual ou endófora, os pronomes demostrativos apresentan propriedades que non sempre coinciden coas asinaladas no ponto anterior ${ }^{27}$. Comezándomos pola deíxe anafórica, obsérvase que os tres graus de asinalamento a respeito do interlocutor non se manteñen como na mostración sensíbel. En principio, podemos achar as tres unidades cando empregadas individualmente, isto é, cando só se utilice un elemento referencial que recupera tamén unha única unidade antecedente, como poñen de manifesto os seguintes exemplos:

Pol-a mar andan as levres, pol-o monte andan as troitas; si che parece mentira, ¡como ésta haiche moitas!

$(C P G$, III 196)

- Díanos un quilo de uvas, ;mouras! [...] /

- ¡Ai! ¡Ai Hortensia! ¡Pra outra vez non digas así!

$-i E$ lo?

- ¡Di negras! ¡Di negras! Esa é unha palabra moi mal dita

(adaptado de Fernández Rei / Hermida Gulías 1996: 117)

No que se refere ás capacidades de un demostrativo poder estar referido a unha heteroxénea gama de antecedentes, as formas variábeis recuperan, através da concordancia en xénero e en número, a unidade sintáctica a que van ligados. Contodo, nalgúns casos en que aínda na actualidade se manifesta unha certa oscilación canto á adscrición xenérica, o pronome demostrativo (mais non só) é un claro exponente desa flutuación na linguaxe, en ocasións estilística (- Din que hai unha pantasma no castelo. - Din, e tamén comentan que este sai pola noite; Se quixeres facerte á mar debes asistir a un cursiño. - Non penso, porque naveguei moito e este mar de Soneira non me parece diferente dos outros) e noutras de natureza dialectal canto ás posibilidades de sinonimia (- Quería dous freixós. - María tamén, mais estas filloas xa están reservadas). En rexistos orais tamén é posíbel detectarmos

\footnotetext{
7 As diferenzas observadas entre a mostración indicial e a deíxe textual teñen levado algúns autores e autoras a matizaren ponderadamente cada un do dous fenómenos É o caso de Klein-Andreu (1996: 306-307), quen, baseándose no percurso histórico do latín ILLE na formación do castelán, indica que a deíxe ten como principal función amosar, encanto que a anáfora se comporta nomeadamente como un recurso de cohesión textual: "However, though I would agree that both deictic and anaphoric uses should be viewed as exploting the same referential function, it is also true that the similarity between them is based only on the point of view of the producer of the discourse, the speaker or writer (or signer): It is the producer who is presumably "doing the same thing" with pronouns, whether is also another co-referent element present or not. But from the (much less studied) point of view of the addresses, anaphoric and deictic uses are quite obviously not the same. Specifically, anaphoric use implies that some kind of redundancy can exist between two mentions of the same referent, whereas deictic uses not".
} 
usos en que se non gardan as particularidades flexivas entre antecedente e pronome, aínda que en tais casos o fenómeno se apresenta comunmente como unha das oscilacións proprias do rexisto falado, non reducíbel, portanto, aos casos asinalados máis arriba:

Vin quen as viu. Amais oíno, quen as viu; po eu nunca as vin porque, nós, sentíamos esas gritas de noite [...]. E nós sentíamos eses, esas gritas

(adaptado de Fernández Rei / Hermida Gulías 1996: 30-31)

Nas estruturas en anáfora asociativa, por outro lado, en que priman con moito as capacidades lexicais sobre as pronominais, poden aparecer demostrativos a concordaren cos substantivos a que fixeren referencia cando empregados con este tipo de recurso cohesivo. No seguinte exemplo verifícase a utilización do masculino e do feminino antecedendo o núcleo da FN, ao paso que o emprego da forma invariábel alude a ambas as agrupacións nominais:

Mira ese conto. Esa, esa cousa. Ai eso foi verdá, e dixéranse os que oíamos, dixeron: - Mira prél, como se lle conoce o que, o que le, o que le e o que estudia (adaptado de Fernández Rei / Hermida Gulías 1996: 116)

Os pronomes invariábeis, á súa vez, poden facer referencia, dada a súa indeterminación, a accións, estados de cousas, procesos, ás palabras que veñen de ser ditas, etc.; as tipoloxías do antecedente, en consecuencia, son moito máis amplas, pois serven tanto para aludiren a unha soa palabra como para un texto de maiores dimensións:

Unha vella fixo papas

e o poto botóullas fora:

hay un ano que foi esto

e inda hox'a vella chora

$(C P G, \mathrm{I} 45)$

Inanque lle pareza mentira, o señor de Sabarei falaba moitas veces conmigo, mao a mao, coma se fora do meu igoal. Era o home máis cómpito do mundo. Contóume isto en Lugo, nunha tasca de Mosqueira

(Fole, LC 94)

Na estrutura anafórica, en alusión ao que acaba de ser dito, tamén poden aparecer os pronomes de $\mathrm{T} 2$ :

Ch. O mesmo que un Anxsel bolo dexsera, ¿è os cabalos?

Ming. Eses coma seus compañeiros, tamen lebaron o mesmo camiño

(Fernández y Neyra, $P G$ 8) 
$O$ artificio de relatar en primeira persoa, aparte de serme o máis doado, axústase ó insistente anceio de refacer unha realidade compartida, repartida, en tipos e vivencias que configuran a miña propria sensibilidade vital: ise ser moitos de cada existencial mencer

\section{(Blanco-Amor, $O B$ 8)}

En ocasións, encóntranse T1 e T2 combinados para aludiren ao mesmo termo a que se referen. É habitual, segundo Cunha / Cintra (1992: 332), que, caso este uso se ache en diálogos, as unidades de T2 indiquen o que foi dito polo interlocutor:

- Tamén se abriu a fiestra sen que naide lle tocara. Saíu do armario un traxe finchado, gris a raias, coma se o vestise un home sen cabeza nin pes. ¿Entende? E saíu voando pola fiestra, de cara á lúa, moi amodiño. ¿Que quería decir isto?

ó cabo de dous minutos de silencio, meu tío respondéu:

- Iso quere decir, Ramona, que vóu morrer, que me acenan dende o camposanto

(Fole, LC 122)

No entanto, o esquema tricotómico québrase no momento en que son precisas máis unidades pronominais, situación en que só son pertinentes os dous extremos da organización deíctica: T1 e T3, ‘non afastado' e ‘afastado e ausente', respectivamente. A literatura lingüística, que sempre ten subliñado a deíxe indicial como ilustración dos usos dos demostrativos, non cadra aquí con exactitude por diferenciar tres graus cando, na anáfora con varios destes pronomes, somente son empregados os dous citados ${ }^{28}$ :

\section{Queríalles moito ó cadelo i ó gato; cecais máis a iste que a aquil}

(Fole, TB 91)

Isto ten a ver, en primeiro lugar e do ponto de vista histórico, coa esencia da referenciación de T2, xa que durante a época medieval era o máis dado a flutuar canto á nova esfera mostrativa asignada. Doutro lado, tamén garda relación coa tendencia das linguas indoeuropeas a consideraren unicamente dous graus de asinalamento deíctico, e, lembrémolo, só son o dominio lingüístico galego-portugués, algunhas variedades de italiano, o español e o catalán literario os sistemas en que continúan a vigorar organizacións trimembres. Son estrañas no noso idioma, portanto, estruturas referenciais anafóricas do tipo Viñeron Brais, Uxío e Pedro. Aquel

\footnotetext{
${ }^{28}$ Véxase Cunha / Cintra (1992: 334), a salientaren que cando se quer "aludir, discriminadamente, a termos já mencionados, servimo-nos do DEMONSTRATIVO aquele para o referido em primeiro lugar, e do DEMONSTRATIVo este para o que foi nomeado por último". Por súa vez, moito máis alo semellan ir Kock / Gómez Molina (1992: 12) cando apontan que "ese parece ser una mera variante de este", xa que "el paradigma de los pronombres, en sentido restringido, se reduce, de hecho, a las formas concordantes de dos morfemas, este y aquel, capacitados para expresar una sola oposición".
} 
chegou de mañá, ese de tarde e este polo serán (?); en tais casos, habilítanse outras solucións, frecuentemente se empregando unha unidade doutro paradigma pronominal (Aquel chegou de mañá, o segundo de tarde e este polo serán / Aquel chegou de mañá, este de tarde e o outro polo serán) ou mesmo todos os elementos pertencentes á mesma clase (O primeiro chegou de mañá, o segundo de tarde e o terceiro polo serán). En certa consonancia con tais restricións de uso, afirmábamos máis arriba que os demostrativos son elementos secundarios na deíxe textual. Con efeito, a seren unidades elementares na indicial, pasan a un rango secundario na anáfora porque, a teor dos exemplos expostos, non son os únicos pronomes capaces de a desenvolveren. Os exemplos anteriores de este, segundo e aquel ou primeiro, segundo e terceiro, poñamos por caso, alternativas todos eles para a recuperación anafórica de máis de dous antecedentes, así o parecen demostrar.

Na relación catafórica, as formas por excelencia son as de T1, que introducen o que vai ser dito inmediatamente a seguir. A lingua oral costuma introducir unha pausa que serve como fin do grupo fónico, ao paso que a linguaxe escrita marca esta relación endofórica fecuentemente mediante os dous pontos verticais (:):

- Mira, Cabada: O que tes que facer agora, é o que eu che vou a decir.

- Vostede dirá.

- Pois isto: casarte

(García Barros, PT 107)

Máis unha vez, a organzación trimembre non se manifesta cos tres graus de asinalamento, pois ve minguada a súa capacidade mostrativa unicamente a un deles ${ }^{29}$. Cousa distinta é cando T2 ou T3 apresentan as mesmas condicións de emprego, xa que en tais circunstancias o que fan é aludiren a algo xa introducido no discurso anteriormente e recuperáreno noutra ocasión (Para non reprobaren deben coñecer ben iso: os paradigmas morfolóxicos do galego; Xa me contou aquilo que vos aconteceu: que tivérades unha viaxe toda chea de incidencias).

3. Se nas modalidades de deíxe anteriores se expresa unha relación de proximidade ou afastamento, sexa de índole locativo-xeográfica ou sexa de carácter textual, a deíxe transposta serve para traer á mente das persoas intervenientes no discurso algo ou alguén que fica fóra das coordenadas espaciais ou discursivas. Por este motivo, dáselle preferencia de uso ao pronome de T3, que xa de por si indica o maior arredamento ('afastado' e 'ausente') en relación ao binomio emisor-receptor. Estas características canto ao uso tórnano moi frecuente en expresións en que se ${ }^{29}$ Véxase Asenjo Orive (1990: 43): "En la catáfora se utiliza exclusivamente el demostrativo ESTE y su
serie". 
evoca ou en que se lembra algo que forzosamente non se acha en correlación deíctica a respeito do acto comunicativo:

Cando eu coñecín a Lamas Carvaxal deixara il xa de ser mozo, estaba cego ou case cego, e andaba metido nas loitas entoldadas e acedas da cativa política ourensá daquiles tempos

(Cuevillas, $P R G$ 97)

E cando lle regalaches aquela bicicleta ó teu afillado, que levara unha matricula de honor no segundo curso. Aquel mesmo día que o teu afillado estrenóu a bici, caíu dela

(Fole, $H N C$ 58)

Hai que asinalar, finalmente, que cada unha das tres tipoloxías da deíxe non exclui taxativamente as outras, pois o tipo de contexto que se compartilla pode obedecer a naturezas distintas. Nas seguintes mostras, por exemplo, aparece un uso de T3 como índice da deíxe transposta xunto a un caso de T1 que explicita unha relación anafórica a respeito dun antecedente, no primeiro caso, ao tempo que nos dous restantes o texto narrativo lexitima $\mathrm{T} 1$ e T2, respectivamente, para aludir ao enunciado anteriormente:

Aquil sitio chámase dende aquila o Relanzo da Fada. Non se sabe quén lle puxo iste belido nome

(Fole, $T B$ 154)

Moa Laibara confesou que se tirara a vida máis por compartillar a Ela co seu amigo Moh Labara. Este, entón, ao contemplar o sorriso embelecado da súa (dos dous) esposa, constata que se cumpre alí unha transgresión

(Ferrín, $A A$ 98)

Sentíase embebedada polo engado tenue do mariñeiro que retorna á súa aldea após de dez anos de navegacións e recoñece por propios os cinco fillos habidos pola súa esposa nese tempo

(Ferrín, $A A$ 89)

\subsubsection{Deíxe polo tipo de contexto compartillado}

Aínda que os casos de demostrativos empregados na anterior tipoloxía de deíxe se apresentan, cando menos no primeiro uso (indicial), como os máis clásicos, non por iso deixan de poder ser recorrentes na outra grande modalidade, se ben cunha utilización xa non tan relevante como a que se observa naquela. Desde esta perspectiva, por exemplo, cumpren certa función na deíxe social, en que o seu máximo exponente é o sistema de tratamento; se mediante este se detectan relacións sociais 
de poder, respeito, cortesía, educación, etc., un demostrativo empregue para manifestar un afastamento emotivo en relación a unha terceira persoa tamén podería englobarse dentro deste marco xeral de natureza sociolóxica tanto para equivaler ao interlocutor como, de xeito especial, para manifestar matices piorativos:

Escoita, Maruxa, a est'home vello

(Sarmiento, C 327)

Eiquí non ensinaban máis que a rezar e isas vellices da historia

(Blanco-Amor, $O B$ 71)

No que se refere á deíxe temporal, os pronomes demostrativos son frecuentemente usados en FFNN a se comportaren sintacticamente como CC. En tais casos é observábel unha correlación temporal entre os tres termos e o tempo verbal empregado, de modo que, poñamos por caso, T3 vai referido frecuentemente ao pasado e T1 ao presente ou futuro; a distinción cronolóxica entre os tres estadios cronolóxicos vén determinada polo verbo, de forma que os pronomes se limitan a indicaren coherencia temporal a respeito do predicado verbal:

Mais val, chora cricas,

beber neste tempo

a barba regada

que chorar à regos

(Sarmiento, C 177)

A reyna, sem folgo,

nà quele momento, nem falou mimgalla

nem fixo menèo

(Sarmiento, C 144)

A organización da deíxe temporal por meio dos tempos verbais, á súa vez, acha un paralelo coa deíxe segundo o contexto compartillado no que se refere ás nocións de anterioridade e posterioridade. A este respeito, Asenjo Orive (1990: 43) indica que o pasado é, obrigatoriamente, anafórico, ao paso que o futuro é catafórico; o presente, por último, "puede tener una deixis ad oculos [indicial] (también de fantasía, como sucede con los otros dos tiempos)".

Por último, a deíxe circunstancial, expresada particularmente através do adverbio así, é susceptíbel de ser indicada por meio de construcións máis ou menos equivalentes e intercambiábeis de que fan parte os demostrativos, xa indicadas ante- 
riormente, do tipo desta maneira, desta sorte, desta traza, deste modo, dese xeito, etc.:

Escomenzou de sandar o primiño e fóiseme o Bartomeu, que diste xeito son os vieiros dos miragres

(Blanco-Amor, $O B$ 66)

- ¡Boh, boh! Tes razón, que desde aquí non se entende nada.

Desta maneira, déronse ausolución un ao outro

(CLU 107)

\subsection{Outros comportamentos dos demostrativos no dominio deíctico}

Deixando de parte os usos xerais dos demostrativos na esfera da deíxe, existen outras utilizacións, relacionadas directamente con aqueles, en que o pronome desempeña unha serie de funcións características. Algunhas destas poderían mellor entrar dominio da expresividade e da estilística, motivo que nos obrigará a tratalas noutro lugar. Mais certos empregos, no entanto, sendo susceptíbeis de se abordaren nun ou noutro lado, aparecen aquí tratados por nos semellaren máis acordes co tema que estamos a desenvolver. De modo resumido, poderíamos distinguir, pois, os seguintes usos dos pronomes que nos ocupan:

a) as unidades de $\mathrm{T} 1$ son con frecuencia empregadas para indicaren relación de parentesco se seguidas dunha das formas en que se manifesta tal relacionamento:

Dígoche a tí que que istes fillos han acabar conmigo a disgustos

(Fole, HNC 23)

b) adoito, recórrese a T2 para se referir directamente ao interlocutor e indicar unha parte do seu corpo. Unha das utilizacións máis frecuentes acontece co substantivo mans, para que Álvarez Martínez (1989: 133), acarón doutros, considera o resultado esas mans xa como unha estrutura fixa:

Pasado mañá é a feira... ¿Estamos? Trato feito. Veñan isas maos

(Fole, TB 195)

Mais, á marxe da presumíbel fixación das extremidades superiores, o seu emprego tamén se acha cunha gama moito maior de nomes substantivos que indican partes de corpo. É moi común, dentro destes, que o enunciado sexa exclamativo, facto que cómpre relacionármolo cos rexistos coloquiais en que proliferan tais construcións: 
- Irey, mais dame un biquiño

Antes que de tí m'aparte,

Qu'eses labiños de rosa

Inda non sei como saben

(Rosalía, CG 31)

Nos mesmos usos, T1 pode facer referencia ao emisor e resulta dunha marcada forza expresiva, sobretodo, como acontece no exemplo a seguir, se se empregar en estruturas reiterativas:

¡Istas mans, ista fronte, iste meu ollar han levar pol-o mundo adiante o esprito do meи pai

(Otero Pedrayo, AMA 81)

c) na mesma liña, fanse acompañar de T2 outros substantivos que aluden igualmente ao interlocutor, como abrazo (Veña ese abrazo!), saúde (Como vai esa saúde?), etc. Tanto nestes como nalgúns dos casos inmediatamente anteriores o demostrativo deixa abesullar matices posesivos:

¿Dame meu querido Mingote, dame ese abrazo para min tan deseado nestos cinco meses que fai que nonos bimos!

(Fernández y Neyra, $P G 5$ )

d) as unidades de T1 serven para indicaren proximidade afectiva ou coloquialidade a respeito dunha persoa que non se acha no contexto comunicativo:

Tí non sabes o que son istes nenos maxinativos na edade do teu fillo

(Otero Pedrayo, AMA 89)

e) en relación directa coa deíxe indicial, en que este, esta e isto asinalan algo marcado polo seu non afastamento en relación ao emisor, os elementos de T1 son tamén empregues para indicaren un espazo físico amplo en que se sitúa o falante:

Benvidas miñas señoras,

benvidas pr'estas aldeas

(García Barros, PT 133)

g) as mesmas formas de T1, aliás, son moi frecuentes para aludiren, en textos escritos, ao que se está a redixir ou para chamaren a atención sobre estes, segundo aponta Porto Dapena (1986: 107). É de notar que en tais casos se pode falar tanto de deíxe indicial (pola proximidade ao que se escrebe) como de deíxe textual (por se facer referencia a un texto); non é de estrañar, por outro lado, que sexan unha das características da instancia prologal: 
Este fato de relatos son continuación de outros que din fai uns anos no meu libro Xente de aquí e de acolá

(Cunqueiro, FE 9)

E tampouco é de estrañar, en congruencia co seu aparecimento nos prólogos, que se atesten na didascalia que introduce un lance, acto, xornada ou calquer división interna dunha peza teatral:

Iste cadro desenrólase nun calabós

(Varela Buxán, FS 147)

h) asemade, a serie de T1 é utilizada para situar algo ou alguén en coincidencia existencial co presente ou co pasado e futuro inmediatos (Porto Dapena 1986: 109), gardando unha estreita relación coa deíxe temporal (e indicial) anteriormente vista:

¡Como aquece iste silenzo, iste ulido de soutos e xardís deixados!

(Otero Pedrayo, TI 85)

i) a serie ese, esa iso, habitualmente índice de algo afastado mais non asusente en que se aponta, a teor dos exemplos anteriores, para o que estiver perto do interlocutor, desenvolve ás veces funcións de identificación, tan afastadas do emisor como do receptor. Un bon exemplo deste comportamento témolo no poema de Lamas Carvajal "O falar d'as fadas", en que a FN esa fala alude ao idioma galego:

\title{
Fálame n-esa fala melosiña
}

que celestiales armunias ten

(Lamas Carvajal, SG 71-73)

1) en ocasións, dentro do ámbito da deíxe textual, pode empregarse unha unidade de T2 cun sentido de totalización, contraposto á equivalente de T1, que só se comportaría como unha marca explícita da endófora:

\author{
Oliveira ben plantada \\ esa si que é oliveira; \\ unha nena ben casada \\ esa sempre parece solteira
}

(CRS 20)

m) finalmente, os pronomes de T2 poden servir para localizaren dun modo indeterminado ou impreciso algo que en xeral é considerado distante: 
¿Non hai xentes senlleiras, caladas, por isas rúas e camiños? ¿Non hai casas fechas nas que parez haberes acabado a calore da vida? ¿Non hai amor por ises boscos e milleirais? ¿Non hai ollos que se erguen para o ceio con espranza ou con asaño? ¿Por qué me queres enzorobellar con toda isa merda, vociferada e retórica, que ti chamas leises, cencias, razóns?

(Blanco-Amor, OGC, II 251)

\section{Conclusións}

Nas páxinas precedentes fíxose un balanzo elementar sobre os pronomes demostrativos no galego e sobre o seu comportamento deíctico partindo de dous grandes tipos de deíxe: a deíxe polo tipo de contexto compartillado (que dá pé a falarmos de deíxe indicial, textual e transposta) e aqueloutra segundo a componente do contexto (que lexitima diferenciarmos unha deíxe persoal, social, temporal e circunstancial). Interesa, nesta altura, sintetizarmos o dito anteriormente e, deste xeito, convén salientarmos en primeiro lugar que os demostrativos, organizados en dous paradigmas, o dos pronomes simples e o dos compostos, son elementos gramaticais como o resto dos pronomes e que poden axir tanto como elementos nucleares na FN como adxacentes, coa excepción de isto, iso e aquilo, que só se comportan como unidades substantivais.

Ditos pronomes estruturan o mundo biosocial a partir do emisor, de aí que cobre sentido indentificármolos como "egocéntricos", pois son xustamente as coordenadas deícticas do EU as que se toman como referencia nesa estuturación. Aínda que cada lingua decide o número de esferas deícticas, o certo é que predominan os sistemas bimembres nunha boa parte das lingua europeas. Sistemas de tres membros son os minoritarios e o galego pertence ao grupo de idiomas que aínda posui, como no latín, organizacións tricotómicas: este (non afastado), ese (afastado e non ausente) e aquel (afastado e ausente).

Hai que ponderar, por último, que, do mesmo modo que o sistema vocálico galego apresenta sete elementos mais non todos poden aparecer en todas as posicións (pretónica, tónica, postónica e postónica final), tamén os demostrativos, organizándose en tres ámbitos deícticos, non participan da mesma recorrencia en todas as tipoloxías de deíxe: no caso da indicial encontramos as tres series, mais no caso da textual o seu número pode verse reducido a dúas (na recuperación anafórica de elementos anteriores), aquel e este, ou mesmo a un, xeralmente este, nas estruturas discursivas catafóricas; na deíxe transposta, por súa vez, son os pronomes da serie de aquel os máis recorrentes nesta modalidade de deíxe; para a deíxe temporal, outrosí, os demostrativos adoitan marcar unha correlación canto ao uso dos tempos verbais (aquel para o antepretérito ou este para o presente poñamos por caso), ao paso que na deíxe social pode apreciarse algún uso dos demostrativos, máis ben de 
carácter estilístico e expresivo, que redunda nun certo distanciamento a respeito da persoa de que se fala ou mesmo o emisor (Non me simpatiza o home ese; Este home non che dá máis cartos porque xa chos dei onte); no que se refere á deíxe circunstancial, son notábeis fórmulas cohesivas do tipo deste xeito, dese modo, desta maneira, etc., moi próximas do multivalente adverbio así, encanto na deíxe persoal cómpre salientarmos os usos estilísticos da FN este + substantivo para ser referir á persoa que emite o texto.

\section{Referencias bibliográficas}

Alarcos Llorach, E. (1976): “Los demostrativos en español”, Verba, 3: 53-63.

Alonso, J. J. (2000): “A orixe da linguaxe”, en Ramallo, F. / Rei-Doval, G. / Rodríguez Yáñez, X. P. (eds.): Manual de Ciencias da Linguaxe: 63-96 (Vigo: Xerais).

Álvarez, R. / Regueira, X. L. / Monteagudo, H. (1993) [1986]: Gramática Galega (Vigo: Galaxia).

Álvarez, R. / Xove, X. (2002): Gramática da lingua galega (Vigo: Galaxia).

Álvarez Martínez, M. A. (1989): El pronombre. Vol. I. Personales, Artículo, Demostrativos, Posesivos (Madrid: Arco / Libros).

Asenjo Orive, Ma . R. (1990): Los demostrativos (Salamanca: Publicaciones del Colegio de España / Centro Internacional de Estudio del Español).

Barboza, J. Soares (1830) [1822]: Grammatica Philosophica da Lingua Portugueza ou Principios da Grammatica Geral Applicados á Nossa Linguagem (Lisboa: Typographia da Academia Real das Sciencias).

Beaugrande, R.-A. de / Ulrich Dressler, W. (1997): Introducción a la lingüística del texto (Barcelona: Ariel).

Bechara, E. (1974): "O sistema dos demonstrativos no português do Brasil”, Archiv für das Studium der neueren Sprachen und Literaturen, 126. Jahrgang / 211. Band: 320-333.

Benveniste, E. (1966): Problèmes de Linguistique Générale. Vol. I (Paris: Gallimard).

Bühler, K. (1979): Teoría del lenguaje (Madrid: Alianza).

Carballo Calero, R (1979) [1966]: Gramática elemental del gallego común (Vigo: Galaxia).

Carré Alvarellos, L. (1967): Gramática gallega (A Cruña: Editorial Moret).

Comrie, B. (1989): Universales del lenguaje y tipología lingüística. Sintaxis y morfología (Madrid: Gredos). 
Cornish, F. (1990): “Anaphore pragmatique, référence, et models du discours", en Kleiber, G. / Tyvaert, J.-E. (eds.): Recherches Linguistiques, XIV. L'Anaphore et ses Domaines: 81-96 (Metz: Centre d'Analyse Syntaxique de la Faculté des Lettres et Sciences Humaines).

Costa, X. X. / González, M. A. / Rábade, X. C. / Morán, C. C. (1988): Nova gramática para a aprendizaxe da língua (A Coruña: Vía Láctea).

Cuesta, P. Vázquez / Luz, M. A. Mendes da. (1989) [1971]: Gramática da Língua Portuguesa (Lisboa: Edições 70).

Cunha, C. Ferreira da / Cintra, L. F. Lindley. (1992) [1984]: Nova Gramática do Português Contemporâneo (Lisboa: Edições Sá da Costa).

Fernández Ramírez, S. (1987) [s.d.]: Gramática española. Vol. 3.2. El pronombre. Preparado por José Polo. (Madrid: Arco / Libros).

Fernández Rei, F. / Hermida Gulías, C. (eds.) (1996): A nosa fala. Bloques e áreas lingüísticas do galego (Santiago de Compostela: Consello da Cultura Galega).

Fonseca, F. I. (1996): "Deixis e pragmática linguística", en Faria, I. Hub / Pedro, E. Ribeiro / Duarte, I. / Gouveia, C. A. M. (orgs.): Introdução à Linguística Geral e Portuguesa: 429-445 (Lisboa: Caminho).

Freixeiro, X. R. (2000): Gramática da lingua galega. Vol. II. Morfosintaxe (Vigo: A Nosa Terra).

Freixeiro, X. R. (2002): Manual de gramática galega (Vigo: A Nosa Terra).

Halliday, M. A .K. / Hasan, R. (1976): Cohesion in English (London: Longman).

ILG [Instituto da Lingua Galega] (1995): Atlas Lingüístico Galego. Vol. II. Morfoloxía non verbal (A Coruña: Fundación Pedro Barrié de la Maza).

Joly, A. (1987): Essays de Systématique Énonciative (Lille: Presses Universitaires de Lille).

Kleiber, G. (1994): Anaphores et Pronoms (Glembloux: Éditions Duculot).

Klein-Andreu, F. (1996): "Anaphora, deixis and the evolution of Latin 'ille", en Fox, B. (ed.): Studies in Anphora: 305-331 (Amsterdam / Philadelphia: John Benjamins).

Kock, J. de / Gómez Molina, C. (1992): "Los pronombres demostrativos en registros análogos y diferentes”, en Kock, J. de / Gómez Molina, C. / Verdonk, R. (eds.): Gramática española. Vol. II. N ${ }^{\circ}$. Los pronombres demostrativos y relativos: 10-90 (Salamanca: Universidad de Salamanca).

Lagares Diez, X. C. (2000): O xénero en galego. Tese de Doutoramento (inédita). Universidade da Coruña. Departamento de Galego-Portugués, Francés e Lingüística. 
Lopes, Ó. (1985): “Algumas particularidades do português, e especialmente do português europeu, que importam á teoria semântica linguística universal”, Actas do Congresso sobre a Situação Actual da Língua Portuguesa no Mundo: 85-104 (Lisboa: ICALP).

Lugrís Freire, M. (1931) [1922]: Gramática do idioma galego (A Cruña: Imprenta Moret).

Matos, M. M. / Muidine, S. A. (1997): “Acó e Aló”, en Castro, I. (ed.): Actas do XII Encontro Nacional da Associação Portuguesa de Linguística. Vol. II: 211-217 (Lisboa: Associação Portuguesa de Linguística).

Mattoso Câmara Jr., J. (1997) [1970]: Estrutura da Língua Portuguesa (Petrópolis: Vozes).

Melo, G. Chaves de. (1986): "Deícticos e anafóricos na língua portuguesa”, Agália, 8: 375-384.

Pérez Sardiña, X. M. (1996): "Os adverbios absolutos de lugar. Achega semántica e dialectal”, Cadernos de Lingua, 13: 89-104.

Porto Dapena, J. A. (1986): Los pronombres (Madrid: Edi-6).

Pottier, B. (1972): Estruturas Lingüísticas do Português (São Paulo: Difusora Europeia do Livro).

Ramallo, F. (2000): "Pragmática”, en Ramallo, F. / Rei-Doval, G. / Rodríguez Yáñez, X. P. (eds.): Manual de Ciencias da Linguaxe: 443-512 (Vigo: Xerais).

Raposo, E. Paiva. (1973): "Sobre a forma $o$ em português", Boletim de Filologia, 22: $361-415$.

Roca-Pons, J. (1982): El lenguaje (Barcelona: Teide).

Saco Arce, J. A. (1868): Gramática gallega (Lugo: Imprenta de Soto Freire).

Teyssier, P. (1989): Manual de Língua Portuguesa (Portugal-Brasil) (Coimbra: Coimbra Editora).

Vilela, M. (1999) [1995]: Gramática da Língua Portuguesa (Coimbra: Livraria Almedina).

Wandruszka, M. (1976): Nuestros idiomas: comparables e incomparables. 2 vols. (Madrid: Gredos). 


\section{Desenvolvimento das abreviaturas e siglas empregadas nas citacións literarias}

Blanco-Amor, $O B=$ Blanco-Amor, Eduardo (1995) [1962]: Os Biosbardos. Contos prá xente (Vigo: Galaxia).

Blanco-Amor, OGC, II = Blanco-Amor, Eduardo (1992): Obra en galego completa . Vol. II. Poesía e teatro (Vigo: Galaxia).

Castelao, OC, I = Alonso Montero, X. (dir.) (1975): Castelao, Obra completa. Vol. I. Narrativa e teatro (Madrid: Akal).

$C L U=$ Centro de Estudos Fingoy (ed.) (1971) [1963]: Contos populares da provincia de Lugo (Vigo: Galaxia).

$C P G=$ Pérez Ballesteros, J. (ed.) (1979) [reimpr. facs. da ed. de 1885-1986]: Cancionero popular gallego. 3 vols. (Madrid: Akal).

$C R S=$ Asociación Xuvenil “Os Estraloxos" (ed.) (1999): Cantigas e refráns da Ribeira Sacra (Ribeira de Pantón: Edición dos autores).

Cuevillas, $P R=$ López Cuevillas, Florentino (1971) [1962]: Prosas galegas (Vigo: Galaxia).

Cunqueiro, FE = Cunqueiro, Álvaro (1981) [1979]: Os outros feirantes (Vigo: Galaxia).

Fernández y Neyra, $P R G$ = Fernández y Neyra, José (1984) [reimpr. facs. da ed. de 1810]: Proezas de Galicia, explicadas baxo la conversación rústica de los dos compadres Chinto y Mingote (Pontevedra: Bibliófilos Gallegos).

Ferrín, $A A=$ Méndez Ferrín, Xosé Luís (1982): Amor de Artur e novos contos con Tagen Ata ao lonxe (Vigo: Xerais).

Fole, LC = Fole, Ánxel (1983) [1953]: Á lús do candil. Contos a carón do lume (Vigo: Galaxia).

Fole, $H N C=$ Fole, Ánxel (1987): Historias que ninguén cre (Vigo: Galaxia).

Fole, $T B=$ Fole, Ánxel (1997) [1955]: Terra brava (Vigo: Xerais).

García Barros, PT = Freixeiro Mato, X. R. (ed.) (1998): Cos pés na Terra. Personalidade e obra inédita ou esquecida de Manuel García Barros: 87-192 (A Estrada: Asociación Cultural "A Estrada” / Edicións Fouce).

Lamas Carvajal, $S G$ = Lamas Carvajal, Valentín (1981) [reimpr. facs. da ed. de 1880]: Saudades gallegas (A Coruña: Real Academia Gallega).

Otero Pedrayo, $A M A$ = Otero Pedrayo, Ramón (1928): Os camiños da vida. Novela en tres partes. II. A maorazga (A Cruña: "Nós", Pubricacións galegas e imprenta). 
Otero Pedrayo, $T I$ = Marco, A. (ed.) (1991): Ramón Otero Pedrayo, Teatro ignorado (Santiago de Compostela: Laiovento).

POGA = Blanco, D. (ed.) (1992): A poesía popular en Galicia. 1745-1885. Recopilación, estudio e edición crítica. 2 Vols. (Vigo: Xerais).

Pondal, $Q P=$ Ferreiro, M. (ed.) (1995): Eduardo Pondal, Poesía galega completa I. Queixumes dos pinos (Santiago de Compostela: Sotelo Blanco).

Rosalía, CG = Pociña, A. / López, A. (eds.) (1993) [1992]: Rosalía de Castro, Poesía galega completa I. Cantares gallegos (Santiago de Compostela: Sotelo Blanco).

Varela Buxán, FS = Varela Buxán, Manuel D. (1975) [s.d.]: O ferreiro de Santán e Taberna sin dono (Lugo: Ediciones Celta).

Sarmiento, $C$ = Mariño Paz, R. (ed.) (1995): Fr. Martín Sarmiento, Coloquio de vintecatro galegos rústicos (Santiago de Compostela: Consello da Cultura Galega). 